\title{
Hepatocyte nuclear factors as possible C-reactive protein transcriptional inducer in the liver and white adipose tissue of rats with experimental chronic renal failure
}

\author{
Elzbieta Sucajtys-Szulc ${ }^{1} \cdot$ Alicja Debska-Slizien ${ }^{1} \cdot$ Boleslaw Rutkowski $^{1} \cdot$ Ryszard Milczarek $^{2}$ • \\ Iwona Pelikant-Malecka ${ }^{3,5} \cdot$ Tomasz Sledzinski $^{2} \cdot$ Julian Swierczynski, ${ }^{3,4} \cdot$ Marek Szolkiewicz $^{1}$
}

Received: 12 June 2017 / Accepted: 4 January 2018 / Published online: 12 January 2018

(c) The Author(s) 2018

\begin{abstract}
Inflammation related to chronic kidney disease (CKD) is an important clinical problem. We recently determined that hepatocyte nuclear factor $1 \alpha(\mathrm{HNF} 1 \alpha)$ was upregulated in the livers of chronic renal failure (CRF) rats-experimental model of CKD. Considering that the promoter region of gene encoding C-reactive protein (CRP) contains binding sites for HNF $1 \alpha$ and that the loss-of-function mutation in the Hnfs $1 \alpha$ leads to significant reduction in circulating CRP levels, we hypothesized that HNF1 $\alpha$ can activate the Crp in CRF rats. Here, we found coordinated upregulation of genes encoding CRP, interleukin-6 (IL-6), HNF1 $\alpha$, and HNF4 $\alpha$ in the livers and white adipose tissue (WAT) of CRF rats, as compared to the pair-fed and control animals. This was accompanied by elevated serum levels of CRP and IL-6. CRP and HNFs' mRNA levels correlated positively with CRP and HNFs' protein levels in the liver and WAT. Similar upregulation of the Crp, Il-6, and Hnfs in the liver and WAT and increased serum CRP and IL-6 concentrations were found in lipopolysaccharide (LPS)-induced systemic inflammation in rats. Moreover, silencing HNFl $\alpha$ in HepG2 cells by small interfering RNA led to decrease in CRP mRNA levels. Our results suggests that (a) HNFs act in concert with IL-6 in the upregulation of CRP production by the liver and WAT, leading to an increase in circulating CRP concentration in CRF rats and (b) CRF-related inflammation plays an important role in the upregulation of genes that encode HNFs and CRP in the liver and WAT of CRF rats.
\end{abstract}

Keywords CRP $\cdot \mathrm{Il}-6 \cdot \mathrm{HNF} 1 \cdot \mathrm{HNF} 4 \cdot \mathrm{LPS} \cdot \mathrm{CRF}$

Electronic supplementary material The online version of this article (https://doi.org/10.1007/s11010-018-3268-1) contains supplementary material, which is available to authorized users.

Boleslaw Rutkowski

bolo@gumed.edu.pl

1 Department of Nephrology, Transplantology, and Internal Medicine, Medical University of Gdansk, Dębinki 7, 80-211 Gdansk, Poland

2 Department of Pharmaceutical Biochemistry, Medical University of Gdansk, Dębinki 1, 80-211 Gdansk, Poland

3 Department of Biochemistry, Medical University of Gdansk, Debinki 1, 80-211 Gdansk, Poland

4 State School of Higher Vocational Education in Koszalin, Lesna 1, 75-582 Koszalin, Poland

5 Department of Medical Laboratory Diagnostics, Central Bank of Frozen Tissues and Genetic Specimens, Medical University of Gdansk, BBMRI.PL, Debinki 7, 80-211 Gdansk, Poland

\section{Introduction}

Chronic kidney disease (CKD) is a complex disorder affecting multiple human organs and systems. The worsening of kidney function and the accumulation of waste products lead to diverse metabolic, and subsequently clinical, disturbances linked to high morbidity and mortality in CKD patients [1, 2]. Persistent low-grade inflammation is a basic feature of CKD patients. It promotes damage to kidneys and initiates and mediates destructive processes in many organs, particularly in the cardiovascular system, leading to high morbidity and mortality rates $[3,4]$.

Several biomarkers have been introduced to diagnose and monitor CKD-related inflammatory states [5, 6]. C-reactive protein (CRP) and interleukin-6 (IL-6) have been shown to be the most potent [7]. Many reports have confirmed that serum CRP and IL-6 concentrations are enhanced in CKD patients and are inversely correlated with glomerular filtration rate (eGFR) [8-10]. Panichi 
et al. [11] showed that IL-6 is a stronger predictor of total and cardiovascular mortality than CRP; however, CRP is the most commonly used clinical marker of inflammation. Moreover, some data suggest that CRP is directly involved in the pathogenesis of coronary heart diseases [12]: it participates in atherogenesis via modulating the expression of genes encoding vascular cell adhesion molecule 1 (VCAM-1), intracellular adhesion molecule 1(ICAM-1), selectin, and monocyte chemotactic protein (MCP-1) in endothelial cells [13-15]. CRP affects basal and stimulated endothelial NO biosynthesis by downregulating the gene encoding endothelial NO synthase (eNOS) [16]. Furthermore, CRP induces upregulation of angiotensin type-1 receptor $\left(\mathrm{AT}_{1}-\mathrm{R}\right)$ in vascular smooth muscle cells [17] and plasminogen activator inhibitor-1 (PAI-1) in endothelial cells [18]. Emerging evidence suggests that elevated circulating CRP concentration has become an independent predictor of coronary heart disease [19].

CRP is synthesized mainly by the liver in response to proinflammatory cytokines, particularly IL-6 $[14,20]$ derived from activated leukocytes [21, 22], adipose tissue [23-25], and in part from the liver [26]. The gene encoding CRP is also expressed in rat [27] and human adipose tissue [28].

Hepatocyte nuclear factor- $1 \alpha$ (HNF $1 \alpha$, also known as TCF1 transcription factor-1) is involved in the transcriptional regulation of a large number of hepatic genes, including genes encoding acute-phase proteins and proteins engaged in lipid metabolism [29]. Recently, we have found upregulation of genes encoding HNF1 $\alpha$ and HNF4 $\alpha$ in the livers of rats with experimentally induced chronic renal failure (CRF) [30]. Given that (a) the promoter region of gene encoding human CRP contains two distinct binding sites, which bind HNF $1 \alpha$ and activate the gene encoding CRP [31], (b) the rat $C r p$ contains four potential binding sites for HNF1 $\alpha$ (TRANSFAC database), and (c) polymorphisms of the HNF1 $\alpha$ in human affects serum C-reactive protein concentration [32-39], we hypothesize that the elevated level of HNF1 $\alpha$, alongside IL-6, may play a crucial role in upregulating the gene encoding CRP in the liver and white adipose tissue (WAT) of CRF rats. In line with the data reported previously, HNF4 $\alpha$ is an upstream transcription factor that activates HNF1 $\alpha$ [40]. It is thus very likely that the reciprocal relationship between HNF $1 \alpha$ and HNF $4 \alpha$ plays a role in the regulation of the expression of genes encoding CRP in experimental CRF.

In this paper, we examine (a) whether HNFs can influence $C r p$ expression in the livers and WAT of rats with experimental CRF and (b) whether changes in $H n f s$ ' and $\mathrm{Crp}$ expression can be associated with inflammation not related with CRF. Moreover, to assess the direct impact of HNF1 $\alpha$ on CRP synthesis, we measured the effect of small interfering RNA on $H N F 1 \alpha$ and subsequently on $C R P$ expression in $\mathrm{HepG} 2$ cells.
Our results suggest that the upregulation of genes encoding HNFs and IL-6 in the liver and WAT of CRF rats is closely associated with the upregulation of CRP. Furthermore, we found that silencing HNF $1 \alpha$ expression in HepG2 cells RNA led to decrease in CRP mRNA levels. These results suggest that HNFs can act in concert with IL-6 in the upregulation of CRP production by the liver and WAT, leading to an increase in circulating CRP concentration in experimental CRF rats. Moreover, the results obtained with rats treated with lipopolysaccharide (LPS) suggest that CRFrelated inflammation plays an important role in upregulating genes that encode HNFs in the liver and WAT of CRF rats.

\section{Materials and methods}

\section{Animals}

The procedures were conducted according to our institutional guidelines for the care and use of laboratory animals.

\section{CRF rats}

The study was performed using 10-week-old male Wistar rats weighing approximately $250 \mathrm{~g}$ at the beginning of the experiment. There were ten animals in each studied group (i.e., CRF, pair-fed, control-sham-operated). CRF was induced by subtotal (5/6) nephrectomy using a dorsal incision [41]. Sham-operated animals served as the control. All animals were kept in individual wire-mesh cages, and CRF and sham-operated rats were allowed free access to tap water and a commercial diet that has been previously described [42]. Pair-fed rats received daily the amount of food corresponding to that consumed by CRF animals and they were allowed free access to tap water. Air temperature in the animal room was set at $22{ }^{\circ} \mathrm{C}$ and the lighting schedule was controlled (12-h light/dark cycles). Six weeks after induction of CRF, blood samples were collected from abdominal aorta under thiopental anesthesia and serum was obtained after centrifugation at $1500 \times \mathrm{g}$ for $10 \mathrm{~min}$. The rats were euthanized (between 8.00 and 10.00 a.m). After collection, pieces $(\sim 0.5 \mathrm{~g})$ of the liver and epididymal WAT were rapidly frozen in liquid nitrogen and stored at $-80{ }^{\circ} \mathrm{C}$ until the expression of the studied genes was determined.

\section{Clofibrate treatment}

Five weeks after the induction of CRF, the rats were given clofibrate $(250 \mathrm{mg} / \mathrm{kg}$ of body weight for seven successive days) as described previously [43]. 


\section{Lipopolysaccharide (LPS) treatment}

Male Wistar rats weighing $250 \mathrm{~g}$ at the beginning of the study were used in experiments with LPS. There were ten animals in each group (LPS-treated and saline-treated). Persistent inflammation was induced in LPS-treated rats by implanting a subcutaneous slow-release ALZET osmotic pump (Model 2ML4; Durect Corporation, Cupertino, CA) to infuse $1 \mathrm{mg} \mathrm{kg}^{-1} \mathrm{day}^{-1}$ of LPS (E. coli O55:B5; Sigma, Missouri, USA) for 4 weeks. $\mathrm{NaCl}(0.9 \%)$ infusion was used in the saline-treated group. The animals were allowed free access to chow and water with a 12-h light/dark cycle. Rats were anesthetized with ketamine and xylazine after 28 days treatment with LPS. Blood samples were collected from an abdominal aorta and serum was obtained after centrifugation at $1500 \times g$ for $10 \mathrm{~min}$. Following collection, pieces $(\sim 0.5 \mathrm{~g})$ of the liver and epididymal WAT were rapidly frozen in liquid nitrogen, and then stored at $-80{ }^{\circ} \mathrm{C}$ until the expression of the studied genes was determined.

\section{Cell culture}

HepG2 cells, a human hepatocellular carcinoma cell line, were obtained from ATCC (ATCC; Manassas, VA). Cells were maintained in standard Minimum Essential Eagle's Medium (MEM; Sigma) with the addition of $2 \mathrm{mM}$ glutamine, $1 \%$ non essential amino acids, $10 \%$ fetal bovine serum, penicillin (100 IU per $\mathrm{mL}$ ), and streptomycin (100 $\mu \mathrm{g}$ per $\mathrm{mL}$ ). Two days before small interfering RNA (siRNA) transfection, HepG2 cells were passaged in 6 -well plates at $10 \times 10^{-4}$ cells per well. Then the cells were cultured at $37{ }^{\circ} \mathrm{C}$ and grown to approximately $70 \%$ confluence.

\section{Small interfering RNA (siRNA) transfection}

Two different sequences of siRNA targeting HNF-1 $\alpha$ were used: (a) Hs-TCF1-2, No SI00011620, and (b) Hs-TCF1-5, No SI03095015. AllStars Negative Control, No 1027280 was used as negative control (siRNA NC). All siRNAs were obtained from Qiagen (Crawley, UK). HepG2 cells treated by lipofectamine were used as controls (CON). HepG2 cells were transfected with siRNA at concentrations of $10 \mathrm{nM}$ (except for dose-effect studies, in which different concentrations between 0 and $50 \mathrm{nM}$ were examined), using $0.1 \%$ (v/v) Lipofectamine RNAiMAX (Invitrogen, Paisley, UK), as described in the manufacturer's protocol. Transfection reactions were performed in serumfree OptiMEM (Invitrogen, Paisley, UK). Cells were harvested after $48 \mathrm{~h}$ and used for total RNA or protein extraction (see below).

\section{RNA isolation}

Total liver and WAT RNA was extracted from the frozen tissue using the guanidinium isothiocyanate-phenol/chloroform method [44]. GenElute ${ }^{\mathrm{TM}}$ Mammalian Total RNA Miniprep Kit (Sigma) was used for isolation of total RNA from HepG 2 cells. The obtained RNA concentration was determined from the absorbance at $260 \mathrm{~nm}$; all samples had a 260/280 $\mathrm{nm}$ absorbance ratio of about 2.0.

\section{cDNA synthesis}

First-strand cDNA was synthesized from $1 \mu \mathrm{g}$ of total RNA (RevertAid First Strand cDNA Synthesis Kit, Thermo Fisher Scientific, USA). Prior to amplification of cDNA, each RNA sample was treated with RNase-free DNase I (Thermo Fisher Scientific, USA) at $37^{\circ} \mathrm{C}$ for $30 \mathrm{~min}$.

\section{Determination of mRNA levels by RT-PCR}

Rat CRP, IL-6, HNF1 $\alpha$, HNF4 $\alpha$, $\beta$-actin, and TBP (TATAbox binding protein) mRNA levels were quantified by RT-PCR using a Chromo4 Real-Time Detection System (Bio-Rad Laboratories, USA). Primers were designed with Sequence Analysis software package (Informagen, Newington, USA) from gene sequences obtained from the Ensembl Genome Browser (http://www.ensembl.org). The rat sequences of primer pairs (sense and antisense) used in this study are presented in Table A in the Supplementary Appendix. Primers for human: (a) HNF1 $\alpha$ (qHsaCED0001918), (b) CRP (qHsaCED0021979), $\beta$-actin (qHsaCED0036269), and (c) TBP (qHsaCID0007122) assayed in HepG2 cells, were obtained from Bio-Rad Laboratories, Inc, USA. Real-time PCR amplification was performed in $20 \mu \mathrm{L}$ volumes using iQ SYBR Green Supermix (Bio-Rad Laboratories, Hercules, CA). Each reaction contained cDNA and $0.3 \mu \mathrm{M}$ of each primer. Control reactions, with omission of the RT step or with no template cDNA added, were performed with each assay. All samples were run in triplicate. To compensate for variations in the amount of added RNA and in the efficiency of the reverse transcription, $\beta$-actin and TBP mRNA levels were quantified in the corresponding samples and the results were normalized to these values. It should be noted that results obtained with $\beta$-actin and TBP (as internal standards) were similar. The relative quantities of transcripts were calculated using the $2^{-\Delta \Delta \mathrm{CT}}$ formula [45]. The results are expressed in arbitrary units, with one unit representing the mean mRNA level determined in a control group. Amplification of specific transcripts was further confirmed by obtaining the melting curve profiles and subjecting the amplification products to agarose gel electrophoresis. 


\section{Western blot analysis of CRP, HNF1a, HNF4a, and $\beta$-actin}

Frozen liver and WAT samples were homogenized in a buffer containing $10 \mathrm{mM}$ Tris- $\mathrm{HCl}(\mathrm{pH} 7.8), 2 \%$ SDS, $10 \mathrm{mM}$ DTT, and proteinase inhibitors (Sigma) and centrifuged at $15,000 \times g$ for $20 \mathrm{~min}$ at $20^{\circ} \mathrm{C}$. Supernatants were collected and the protein concentration was determined by Bradford assay. Tissue lysates containing $20 \mu \mathrm{g}$ (liver) or $60 \mu \mathrm{g}$ (WAT) of total protein were separated by $10 \%$ SDS-PAGE and electroblotted onto Immobilon Transfer Membrane (Millipore). The following antibodies were used: monoclonal antibody against CRP (sc-69770, Santa Cruz Biotechnology), monoclonal antibody against HNF-1 (sc-393925, Santa Cruz Biotechnology), polyclonal antibody against HNF-4 (sc-8987, Santa Cruz Biotechnology), and polyclonal antibody against Actin (sc-7210, Santa Cruz Biotechnology). HRP-conjugated secondary antibodies (sc-2030 and sc-2004) were obtained from Santa Cruz Biotechnology and the HAF019 from R\&D Systems. Immunodetection was accomplished with enhanced chemiluminescence using western blotting Luminol Reagent (sc2048, Santa Cruz Biotechnology).

Harvested HepG2 cells were suspended in $250 \mathrm{mM}$ sucrose, $10 \mathrm{mM}$ Tris- $\mathrm{HCl}$ (pH 7.8), 2 mM EDTA, and centrifuged $600 \times g$ for $10 \mathrm{~min}$ at $4{ }^{\circ} \mathrm{C}$. Obtained pellet (containing crude nuclear fraction) was suspended in a RIPA buffer ( $150 \mathrm{mM} \mathrm{NaCl}, 1 \% \mathrm{NP} 40,0.5 \%$ deoxycholate, $0.1 \%$ SDS, $50 \mathrm{mM}$ Tris $\mathrm{pH} 8.0$, complete protease inhibitor cocktail), homogenized, and centrifuged $15,000 \times g$ for $20 \mathrm{~min}$ at $4{ }^{\circ} \mathrm{C}$. Supernatants (nuclear lysate) were collected and protein concentration was determined with Bradford assay. The samples of nuclear lysates, containing $30 \mu \mathrm{g}$ of total protein, were separated by $10 \%$ SDS-PAGE and electroblotted onto Immobilon ${ }^{\circledR}$ Transfer Membrane (Millipore). The following antibodies were used: monoclonal antibody against HNF-1 (sc-393925, Santa Cruz Biotechnology) and polyclonal antibody against proliferating cell nuclear antigen (PCNA) (sc-7907, Santa Cruz Biotechnology).

\section{Determination of serum CRP and IL-6 concentration}

Commercially available ELISA kits were used to estimate IL-6 (R\&D Systems, Minneapolis, USA) and CRP (BioVendor - Laboratorni Medicina, Brno, Czech Republic) serum concentrations.

\section{Serum creatinine and blood urea nitrogen (BUN) concentration}

Serum creatinine and BUN concentrations were determined using a Hitachi 704 autoanalyzer.

\section{Database sequence analysis}

The putative HNF $1 \alpha$ binding sites of rat $C r p$ were sought in TRANSFAC database (BIOBASE, Beverly, MA). The sequence covering 2000 bp upstream and 300 bp downstream the transcription start site of rat $\mathrm{Crp}$ was analyzed.

\section{Statistics}

The statistical significance of differences between groups was assessed by one-way analysis of variance (ANOVA) followed by Student's $t$ test and one-way analysis of variance (ANOVA), followed by Tukey's post hoc test. The Sigma Stat software (SyStat) was used. The results are presented as means \pm SDs. Differences between groups were considered significant when $p<0.05$. The relations between two variables were calculated using the Pearson's correlation.

\section{Results}

To validate CRF experimental model, first we determined serum concentrations of creatinine and BUN, the most commonly used markers of renal function. Serum creatinine and BUN concentrations found in CRF rats were a few times higher than those in control and pair-fed animals (Table 1). Simultaneously, the serum concentrations of CRP were significantly higher in CRF rats when compared with control and pair-fed animals (Table 1). Moreover, circulating CRP concentration positively correlated with serum concentration of creatinine $(r=0.92, p<0.001)$ and BUN $(r=0.93$, $p<0.001)$. Circulating IL-6 concentration was also significantly increased in CRF rats as compared with control and pair-fed animals (Table 1). Additionally, strong positive correlations between serum creatinine concentration and

Table 1 Serum markers of renal function (creatinine, BUN) and markers of inflammatory state (CRP and IL-6) of control (CON), pair-fed (PF), and chronic renal failure (CRF) rats

\begin{tabular}{lccc}
\hline Markers & \multicolumn{1}{l}{ CON } & \multicolumn{1}{l}{ PF } & \multicolumn{1}{l}{ CRF } \\
\hline Creatinine $(\mathrm{mg} / \mathrm{dL})$ & $0.5 \pm 0.1$ & $0.6 \pm 0.1$ & $2.4 \pm 0.7^{*}$ \\
BUN $(\mathrm{mg} / \mathrm{dL})$ & $18.8 \pm 4.4$ & $21.2 \pm 3.4$ & $95.3 \pm 15.3^{*}$ \\
CRP $(\mu \mathrm{g} / \mathrm{mL})$ & $179.1 \pm 19.7$ & $219.0 \pm 41$ & $392.3 \pm 42.7^{*}$ \\
IL-6 $(\mathrm{pg} / \mathrm{mL})$ & $131.2 \pm 15.1$ & $147.4 \pm 32$ & $371.2 \pm 54.1^{*}$ \\
\hline
\end{tabular}

The data are presented as mean \pm SD. Statistics: ${ }^{*} p<0.05$ versus CON and versus PF; $n=10$ in each group 
serum IL-6 concentrations ( $r=0.65, p<0.001)$ were found. The above-presented results suggest that in our experimental CRF model circulating CRP and IL-6 concentrations increased in response to renal insufficiency.

Liver CRP mRNA levels were approximately twice as high in CRF rats than in the control and pair-fed animals (Fig. 1a). Figure 1b shows, that the abovementioned intergroup differences in CRP mRNA levels were reflected by different levels of CRP protein levels (Fig. 1b, top panel-representative western blots and bottom paneldensitometric analysis of western blots bands). Moreover, CRF was associated with a significant increase in WAT CRP mRNA levels (Fig. 1c); however, a decrease in CRP mRNA levels in the pair-fed group was found. The pattern of changes in WAT CRP mRNA levels was also consistent with the profile of WAT CRP protein levels (Fig. 1d, top panel-representative western blots and bottom paneldensitometric analysis of western blots bands). Overall,
Fig. 1 Expression of gene encoding CRP in the liver and WAT of control (CON-empty bar), pair-fed (PF-shaded bar), and chronic renal failure (CRFfilled bar) rats: a relative liver CRP mRNA levels; $\mathbf{b}$ representative western blots (top panel) and densitometric analysis of western blots bands (bottom panel) of liver CRP protein; c relative WAT CRP mRNA levels; $\mathbf{d}$ representative western blots (top panel) and densitometric analysis of western blots bands (bottom panel) of WAT CRP protein. Graphs represent the mean \pm SD of results from ten rats. $\beta$-actin and TBP mRNA levels were quantified in the corresponding samples and the results regarding CRP mRNA levels were normalized to these values (a.u. arbitrary units); for details see "Materials and methods." $\beta$-actin was used as a standard for protein level calculation. Statistics: ${ }^{*} p<0.05$, n.s. not significant

\section{Liver}

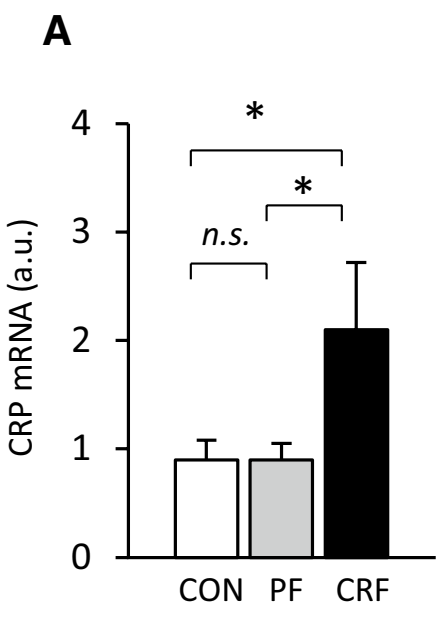

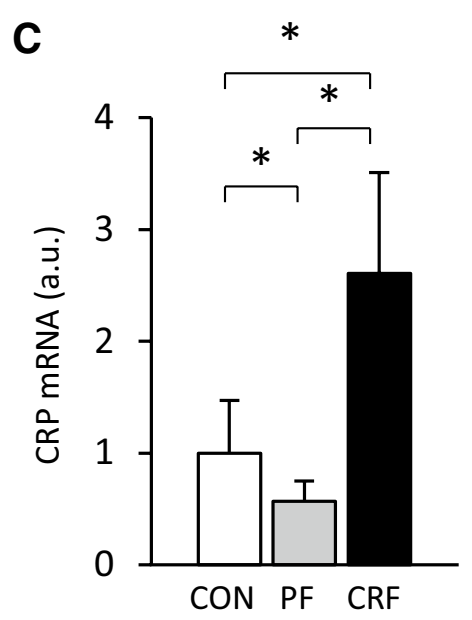

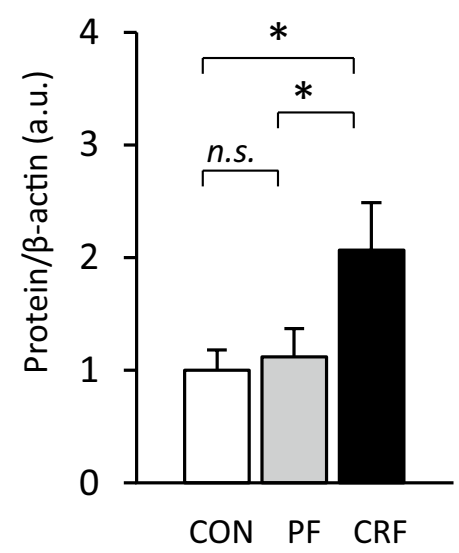


the results presented in Fig. 1 indicate that upregulation of gene encoding CRP takes place in the liver and WAT of CRF rats. Additionally, positive correlations between serum creatinine concentration and (a) liver CRP mRNA level $(r=0.96, p<0.001)$ and (b) liver CRP protein amount $(r=0.98, p<0.001)$ were found. Essentially similar relationships between serum creatinine concentrations and (a) WAT CRP mRNA levels $(r=0.93, p<0.001)$, (b) WAT CRP protein levels $(r=0.95, p<0.001)$ were also found.

Upregulation of the gene encoding liver and WAT CRP (data presented above) was closely associated with increases in levels of liver and WAT HNF1 $\alpha$ mRNA (Fig. 2a, c, respectively). The pattern of differences in liver and WAT HNF1 $\alpha$ mRNA levels was similar to that observed in liver and WAT HNF1 $\alpha$ protein levels, as determined by western blot (Fig. 2b, d, respectively; top panel-representative western blots and bottom panel-densitometric analysis of western blots bands). Strong positive correlations between liver HNF1 $\alpha$ mRNA level and (a) circulating CRP concentration $(r=0.83, p<0.001)$ and (b) liver CRP mRNA level $(r=0.78, p<0.001)$ were found. Strong positive correlations between levels of liver HNF1 $\alpha$ protein and (a) circulating CRP concentration $(r=0.95, p<0.001)$, (b) liver CRP mRNA level $(r=0.85, p<0.001)$, and (c) liver CRP protein levels $(r=0.89, p<0.001)$ were also observed.

Liver and WAT HNF $4 \alpha$ mRNA levels were also elevated in CRF rats, compared with the control and pair-fed animals (Fig. 2e, g). The pattern of differences in liver and WAT HNF $4 \alpha$ mRNA levels was similar to that observed in liver and WAT HNF4 $\alpha$ protein levels (Fig. $2 \mathrm{f}$, h, respectively; top panel-representative western blots and bottom panel-densitometric analysis of western blots bands) of all the control, pair-fed, and CRF rats. Moreover, strong positive correlations between liver HNF $4 \alpha$ mRNA and HNF $1 \alpha$ mRNA levels $(r=0.91, p<0.001)$, as well as between HNF4 $\alpha$ and HNF1 $\alpha$ protein levels $(r=0.92, p<0.001)$ were found.

Considering that the promoter region of the gene encoding (a) human CRP contains two distinct regions, which bind HNF $1 \alpha$ and activate the gene encoding CRP [31], and (b) rat CRP contains four potential binding sites for HNF1 $\alpha$, it is very likely that upregulation of the $C r p$ is a consequence of the increased expression of the Hnfl $\alpha$. Accordingly, treatment with clofibrate, which is capable of decreasing liver mRNA levels of the HNFs [30], coordinately reduces HNF $1 \alpha, H N F 4 \alpha$, and CRP mRNA levels in the liver of the CRF animals (Fig. 3).

To verify if the abovementioned changes in $C R P$ expression were truly caused by changes in HNF1 $\alpha$ protein levels, we assessed Hnfl $\alpha$ deregulation in hepatocellular model (HepG2 cells) by silencing its endogenous expression using small interfering RNA (siRNA). As shown in Fig. 4, the decrease in HNF1 $\alpha$ mRNA (Fig. 4a) and HNF1 $\alpha$ protein levels (Fig. 4b) by two different siRNAs were associated with the decrease in CRP mRNA level (Fig. 4c). Taken together, the results presented above indicate that HNF1 $\alpha$ is involved in the regulation of $C R P$ expression in the liver cells (and possibly in WAT), leading to an increase in circulating CRP concentration in experimental CRF rats.

It is well known that the gene encoding CRP is upregulated by proinflammatory cytokines, including IL-6 [20], derived partially from adipose [24, 25] and liver [26] tissue. As shown in Table 1, serum IL-6 concentration was significantly increased in CRF rats as compared with control and pair-fed animals. The elevated serum IL- 6 concentration was associated with increased liver (Fig. 5a) and WAT (Fig. 5b) IL-6 mRNA levels. Additionally, strong positive correlations between serum creatinine concentration and (a) liver $(r=0.62, p<0.001)$ and WAT $(r=0.84, p<0.001)$ IL-6 mRNA levels and (b) serum IL-6 concentrations $(r=0.65$, $p<0.001$ ) were found.

These data, along with recently published data [46, 47], suggest that CKD-related inflammation may be responsible for the upregulation of the Hnf and Il-6, and subsequently the upregulation of the Crp. To verify this, we treated healthy rats with LPS, an endotoxin that induces an acutephase response [48]. LPS administration did not influence serum creatinine $(0.6 \pm 0.1$ vs. $0.5 \pm 0.1 \mathrm{mg} / \mathrm{dL}$; n.s.) or BUN $(19.8 \pm 1.4$ vs. $18.6 \pm 2.4 \mathrm{mg} / \mathrm{dL}$; n.s.) concentrations, but led to a significant increase in circulating CRP (Fig. 6a) and IL-6 (Fig. 6b) levels. Moreover, the increase in circulating CRP and IL-6 levels observed after LPS treatment was paralleled by an increase in all (a) liver (Fig. 7a) and WAT (Fig. 7e) CRP mRNA levels, (b) liver (Fig. 7b) and WAT (Fig. 7f) HNF1 $\alpha$ mRNA levels, (c) liver (Fig. 7c) and WAT (Fig. 7g) HNF4 $\alpha$ mRNA levels, and (d) liver (Fig. 7d) and WAT (Fig. 7h) IL-6 mRNA levels. This suggests that the effect of CRF and LPS on the Crp, Il-6, and Hnfs was essentially similar.

\section{Discussion}

We have shown for the first time that the experimental CRF-related increase in circulating CRP concentration is a result of its overproduction in the liver and WAT. Given that WAT is a much larger organ than the liver (particularly in humans), it can be supposed that the total amount of CRP synthesized in adipose tissue may be quite significant as a source of circulating CRP. This is partly supported by reports indicating that fat mass in obese subjects is strongly correlated with circulating CRP concentration [49].

Moreover, the data presented in this paper suggest that increased liver and WAT CRP biosynthesis may be mediated not only by IL-6 (as is generally accepted), but also by HNF $1 \alpha$. Considering together (a) that the Crp is a target of HNF1 $\alpha$ [29, 31, 50], (b) the strong positive correlation 
Liver

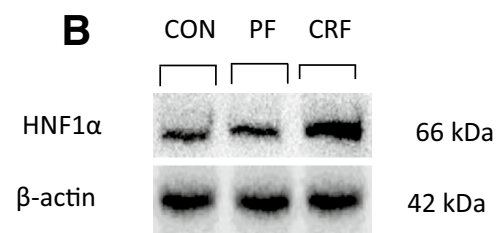

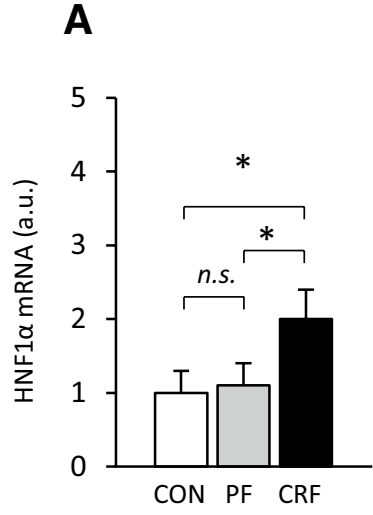

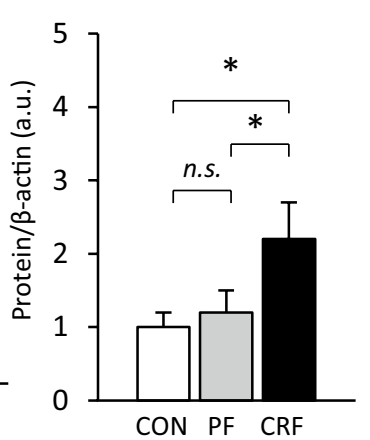

WAT

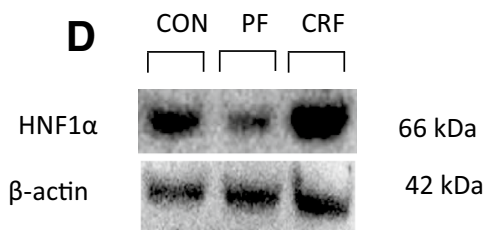

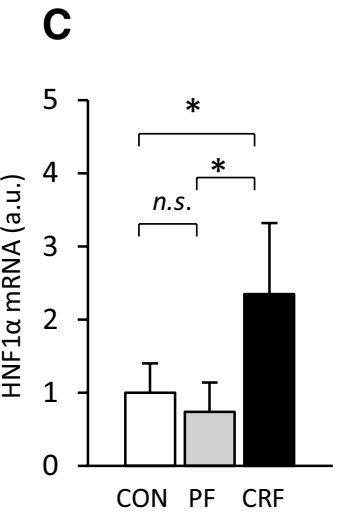

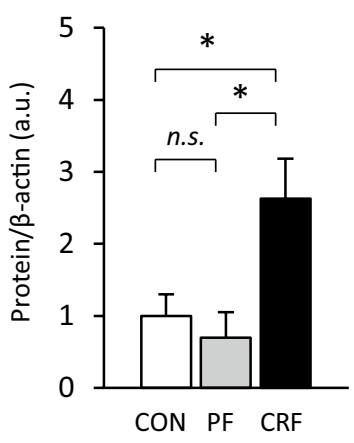

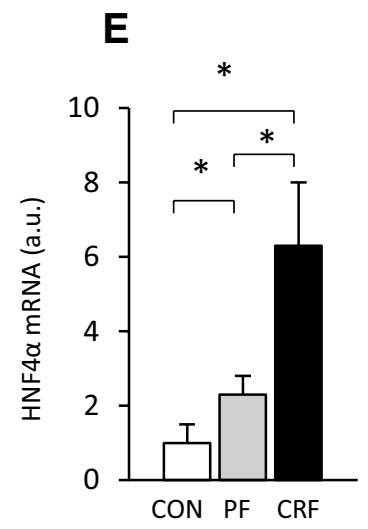
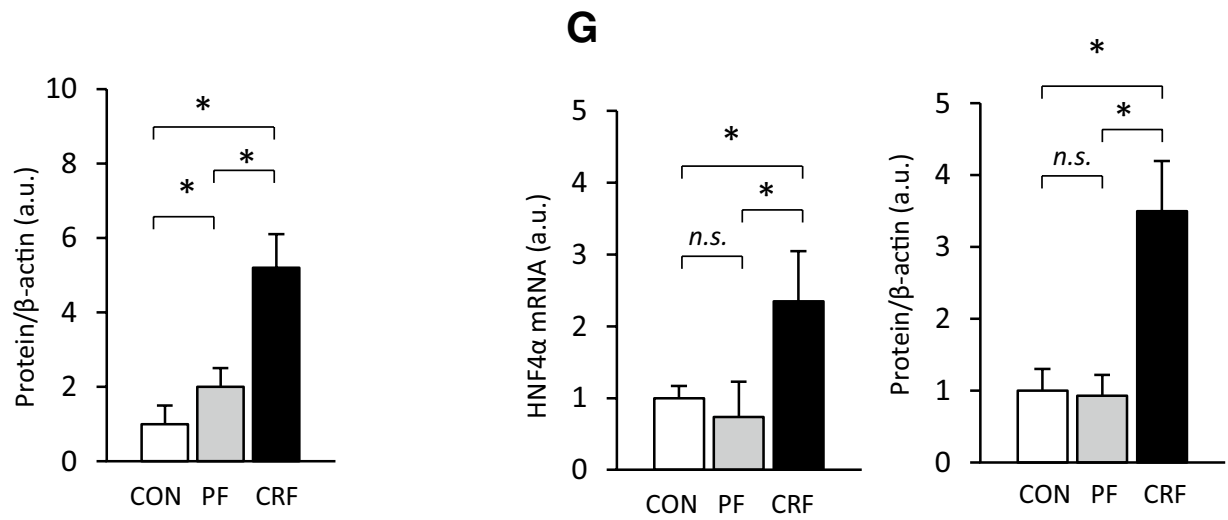

Fig. $2 H n f l \alpha$ and $H n f 4 \alpha$ expression in control (CON-empty bar), pair-fed (PF-shaded bar), and chronic renal failure (CRF-filled bar) rats: a relative liver and c WAT HNF1 $\alpha$ mRNA levels; e relative liver and $\mathbf{g}$ WAT HNF $4 \alpha$ mRNA levels; b representative western blot analysis (top panel) and densitometric analysis of western blots bands (bottom panel) of liver HNF1 $\alpha$ protein levels; $\mathbf{d}$ representative western blot analysis (top panel) and densitometric analysis of western blots bands (bottom panel) of WAT HNF1 $\alpha$ protein levels; $\mathbf{f}$ representative western blot analysis (top panel) and densitometric analysis

of western blots bands (bottom panel) of liver HNF $4 \alpha$ protein levels; $\mathbf{h}$ representative western blot analysis (top panel) and densitometric analysis of western blots bands (bottom panel) of WAT HNF $4 \alpha$ protein levels. Graphs represent the mean \pm SD of results from ten rats. $\beta$-actin and TBP mRNA levels were quantified in the corresponding samples and the results regarding HNFs' mRNA levels were normalized to these values (a.u. arbitrary units); for details see "Materials and methods." $\beta$-actin was used as a standard for protein level calculation. Statistics: $* p<0.05$, n.s. not significant 


\section{Liver}

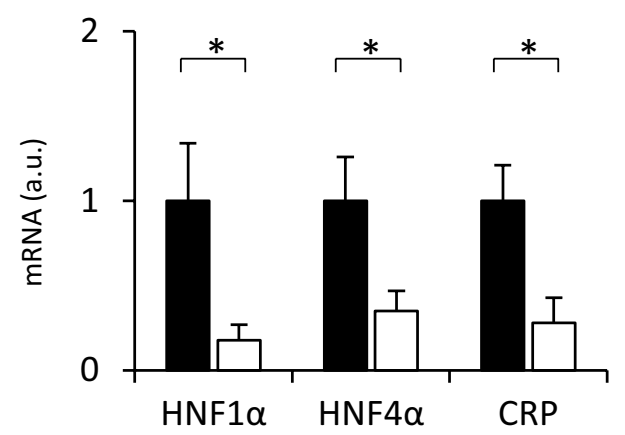

Fig. 3 Relative HNF1 $\alpha, H N F 4 \alpha$, and CRP mRNA levels in the liver of untreated (CRF-filled bar) and clofibrate-treated (CRF+Clofibrateempty bar) rats with chronic renal failure. Graphs represent the mean \pm SD of results from ten rats. $\beta$-actin and TBP mRNA levels were quantified in the corresponding samples and the results regarding HNFs' and CRP mRNA levels were normalized to these values (a.u. arbitrary units); for details see "Materials and methods." Statistics: $* p<0.05$

between Crp and Hnfl $\alpha$ expression found in the liver and WAT, and (c) the coordinate reduction in the expression of the Hnfl $\alpha$ and Crp caused by clofibrate (which is believed to reduce $H n f l \alpha$ expression [30]), we propose that HNF1 $\alpha$ plays a key role in the upregulation of the $C r p$ in CRF rats. Finally, the role of HNF1 $\alpha$ in regulation of Crp was confirmed by results presented in Fig. 4, which shows that silencing of Hnfl $\alpha$ with small interfering RNA (siRNA), led to the decrease in CRP mRNA levels. This is consistent with reports showing that the loss-of-function mutations in the HNF1 $\alpha$-encoding gene associated with maturity-onset diabetes of the young (MODY) lead to a significant reduction in circulating CRP concentrations [51, 52]. Moreover, it has been documented that the polymorphism of Hnfl $\alpha$ is associated with the circulating CRP alterations in healthy subjects [53, 54]. All these confirm that Hnfl $\alpha$ expression and circulating CRP concentration are closely related to each other, and this phenomenon is observed in various pathophysiological conditions. Thus, it can be supposed that the increased intracellular HNF1 $\alpha$ levels found in the liver and WAT of CRF rats may significantly affect CRP synthesis, independently of IL-6, and subsequently increase circulating CRP concentration.

It has previously been shown that Hnfl $\alpha$ expression is highly dependent on the intracellular HNF4 $\alpha$ level (HNF4 $\alpha$ is an upstream HNF1 $\alpha$ transcription factor [40]). It is thus very likely that elevated HNF4 $\alpha$ levels (caused by the increase in expression of its gene) led to increased HNF1 $\alpha$

\section{HepG2}
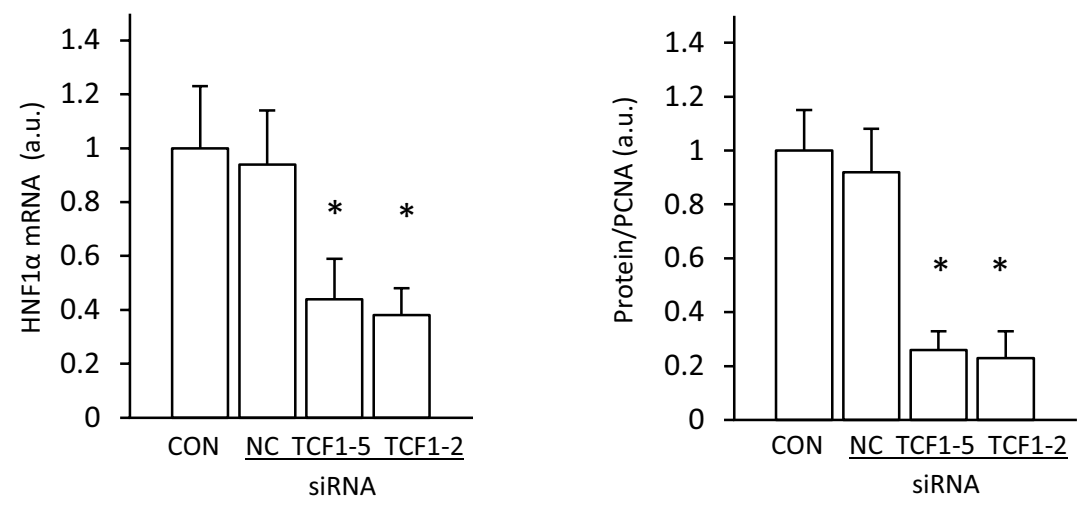

$66 \mathrm{kDa}$

$36 \mathrm{kDa}$
Fig. 4 Coordinated inhibition of $H N F 1 \alpha$ and $C R P$ expression in HepG2 cells by two different sequences of siRNA targeting $H N F-1 \alpha$. a HNF1 $\alpha$ mRNA level and b representative western blot analysis (top panel) and densitometric analysis of western blots bands (bottom panel) of HNF1 $\alpha$ protein levels in lipofectamine-treated HepG2 cells (CON), cells transfected with siRNA targeting HNF-1 $\alpha$ (TCF1-2 or TCF1-5) or negative control (NC). c CRP mRNA level in HepG2 cells treated as described above. For other experimental conditions see "Materials and methods." Graphs represent the mean \pm SD of results from 6 plates performed in three different experiments. Statistics: $* p<0.05$ 
Fig. 5 Relative liver (a) and WAT (b) IL-6 mRNA levels of control (CON-empty bar), pair-fed (PF-shaded bar), and chronic renal failure (CRF-filled bar) rats; Graphs represent the mean $\pm \mathrm{SD}$ of results from ten rats. $\beta$-actin and TBP mRNA levels were quantified in the corresponding samples and the results regarding IL-6 mRNA levels were normalized to these values (a.u. arbitrary units); for details see "Materials and methods." Statistics: ${ }^{*} p<0.05$, n.s. not significant

Fig. 6 Serum CRP (a) and IL-6 (b) concentrations in salinetreated (SALINE-empty bar) and lipopolysaccharide-treated (LPS-filled bar) rats. Graphs represent the mean \pm SD of results from ten rats. Statistics: $* p<0.05$

\section{Liver}
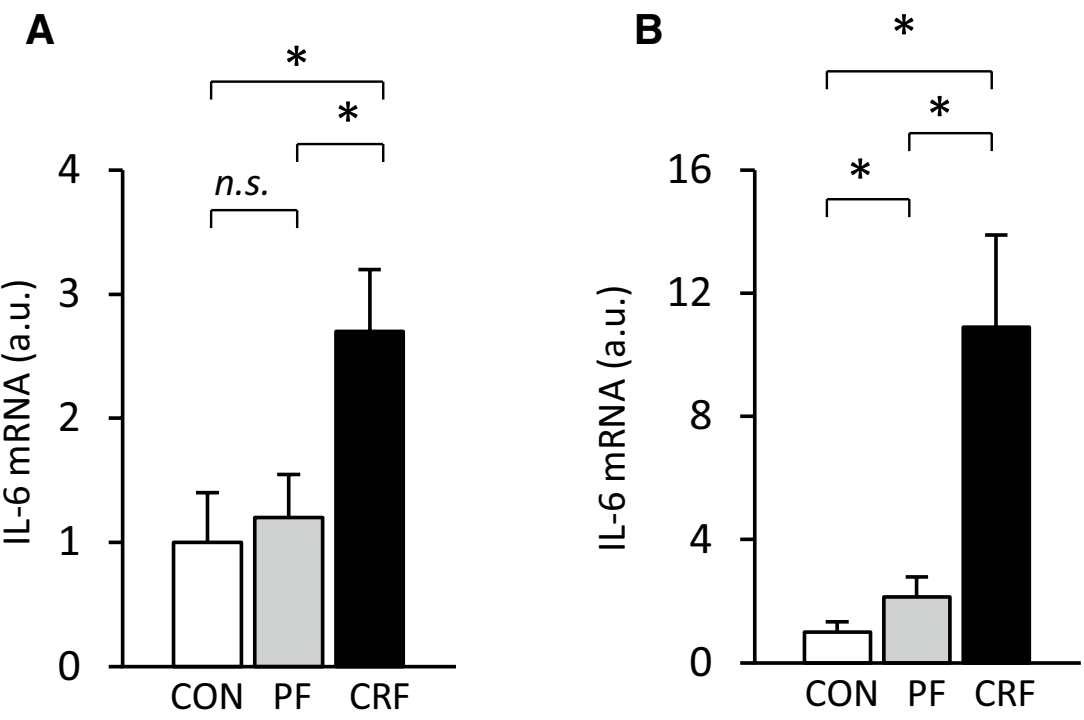

A

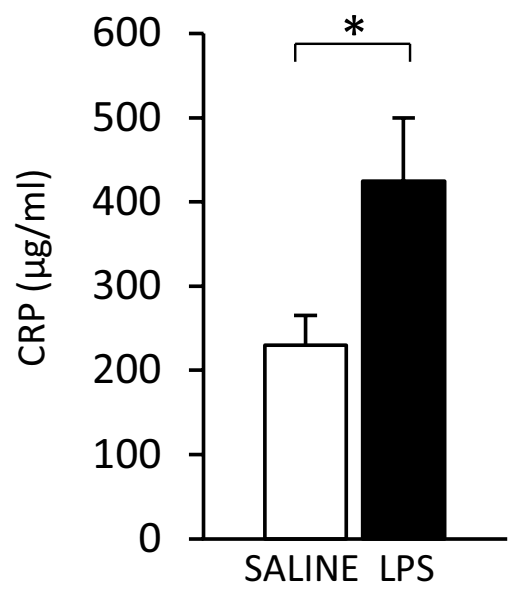

B

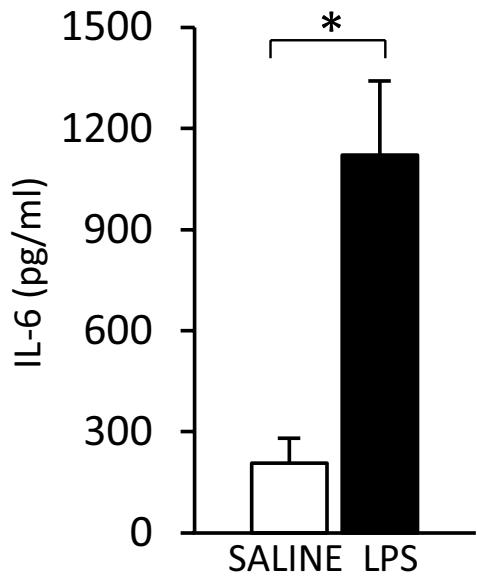

activity. In turn, through its binding to APRE 1 and APRE 2 sequence of the $C r p$ gene, HNF1 $\alpha$ may play a crucial role in upregulation of the Crp in both the liver and WAT of CRF rats. Given that HNF1 $\alpha$ also upregulates the expression of the $H n f 4 \alpha$ [40], it seems that this reciprocal relationship between HNF1 $\alpha$ and HNF4 $\alpha$ is highly important in the regulation of Crp expression in experimental CRF.

It should be emphasized that HNF $1 \alpha$ was initially identified in the liver, but that expression of Hnfl $\alpha$ was later found in the pancreas, intestine, and kidney [55]. The data reported here indicate that rat adipose tissue could be added to the list of tissues and organs expressing HNF1 $\alpha$ and HNF4 4 .

Circulating IL-6 is an essential regulator of a number of acute-phase response genes, including the $\operatorname{Crp}[50,56]$. Enhanced liver and adipose tissue CRP synthesis, and subsequently the elevated circulating CRP concentration found in CRF rats, could therefore result from the increased production of proinflammatory cytokines, particularly IL-6 [20]. This study showed a significantly increased circulating level of IL-6 in CRF rats (Table 1), which was associated with 


\section{Liver}
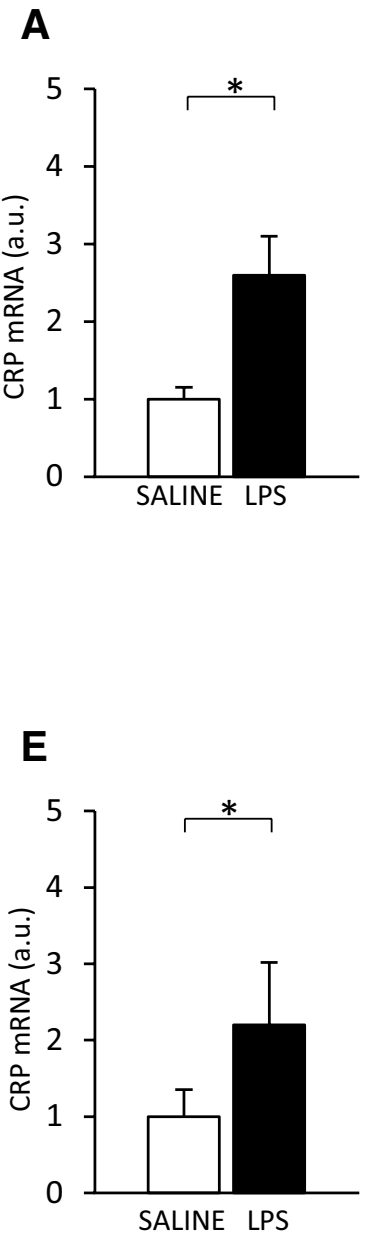

B

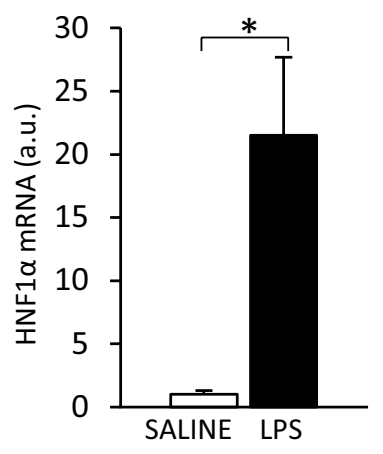

WAT

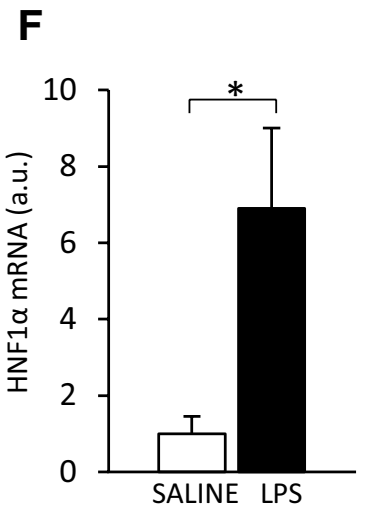

Fig. 7 Relative liver CRP (a), HNF1 $\alpha$ (b), HNF4 $\alpha$ (c), and IL-6 (d) mRNA levels and relative WAT CRP (e), HNF1 $\alpha$ (f), HNF4 $\alpha(\mathbf{g})$, and IL-6 (h) mRNA levels in saline-treated (SALINE-empty bar) and lipopolysaccharide-treated (LPS-filled bar) rats. Graphs represent the mean \pm SD of results from ten rats. $\beta$-actin and TBP mRNA levels

higher IL-6 mRNA levels in the liver (Fig. 5a) and WAT (Fig. 5b). Taken together, it seems that the upregulation of the Il-6 and the Hnfs in liver and WAT tissue is closely associated with the upregulation of Crp. It seems that IL-6 and the HNFs and act in concert to induce CRP overproduction in the liver and WAT, leading to the high circulating concentrations of CRP observed in experimental CRF rats. Considering the data published by Nishikava et al. [50], the increased levels of serum cytokines (IL-1 and IL-6) present in CRF rats may result in the formation of heteromeric complexes consisting of HNF1 $\alpha$, c-Fos, and STAT3, which may in turn stimulate the expression of the Crp. However, further studies are necessary to confirm this suggestion.

The mechanism underlying the upregulation of Hnfl $\alpha$ and $H n f 4 \alpha$ in CRF rats remains elusive. Administration of LPS ( $1 \mathrm{mg}$ per $\mathrm{kg}$ of body mass each $24 \mathrm{~h}$ for 28 days)

C
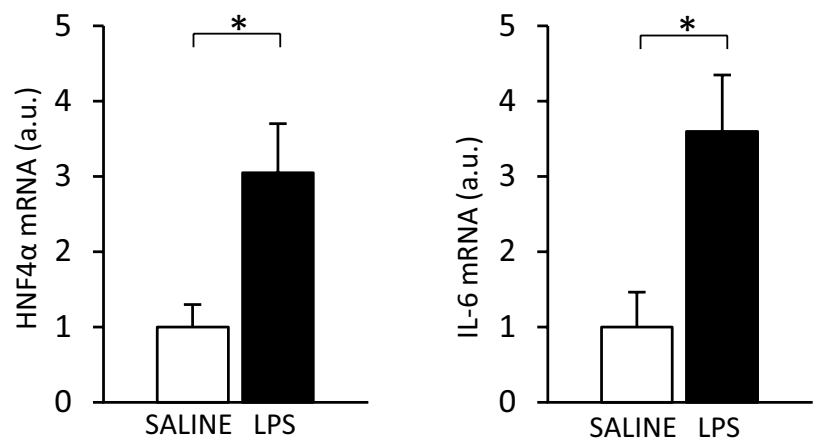

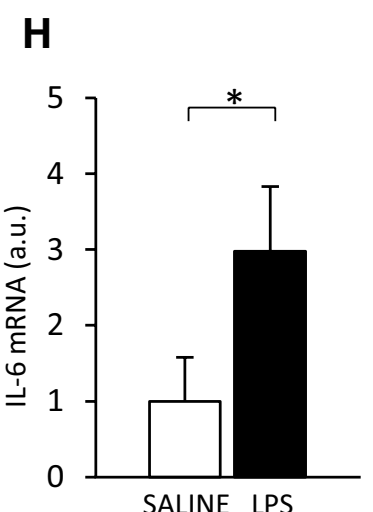

were quantified in the corresponding samples and the results regarding HNFs' and CRP mRNA levels were normalized to these values (a.u. -arbitrary units); for details see "Materials and methods." Statistics: $* p<0.05$

to healthy rats induced upregulation of the liver and WAT $H n f s$, which was associated with a significant increase in Crp expression, despite the fact that renal function did not change. These data suggest that the CRF-related inflammation itself may play an important role in upregulation of the $H n f \mathrm{~s}$, and subsequently in the overexpression of $C r p$. It is worth noting that quite different results were presented by Wang et al. [57], who reported a marked decrease in liver HNF $4 \alpha$ and HNF1 $\alpha$ protein levels in rats following administration of LPS. They suggested that the decrease in $\mathrm{HNF} 4 \alpha$ is primarily the result of the protein post-transcriptional degradation, since hepatic levels of HNF $4 \alpha$ mRNA did not change. This discrepancy is likely due to the fact that Wang et al. [57] tested a short-term effect of the acutephase response induced by a very high dose of LPS (the rats were euthanized only $3 \mathrm{~h}$ after administration of a single, 
very high LPS dose of 5 or $15 \mathrm{mg} / \mathrm{kg}$ body mass). They noted that the decrease in the level of HNF4 $\alpha$ protein was more pronounced in the rats that received the higher LPS dose. We tested a long-term effect of persistent inflammation induced by a significantly lower LPS dose (with the rats being euthanized after 28 days of continuous subcutaneous administration of the low LPS dose of $1 \mathrm{mg} / \mathrm{kg}$ body mass). These results cannot be directly compared with each other, although the long-lasting inflammation induced by LPS seen in our experimental model seems to more accurately resemble the CRF-related inflammatory state.

In conclusion, the results presented here indicate that, in rats with experimental CRF, the liver and WAT Crp, Il-6, $H n f l \alpha$, and $H n f 4 \alpha$ are overexpressed. One of the effects of this coordinated activity is an increase in circulating CRP levels. Moreover, in vitro studies indicate that silencing of Hnfl $\alpha$ expression by siRNA led to the decrease in CRP mRNA level. The data allow us to recognize that HNFs, alongside IL-6, play an important role in the upregulation of Crp gene in the liver and WAT of CRF rats, and presumably in CKD patients. Although the molecular mechanism underlying the upregulation of the Hnfs in CRF rats remains elusive, it seems that chronic persistent inflammation plays a crucial role in this process.

Funding This work was supported by grants ST-4, ST- 40, and ST-41, from the Medical University of Gdańsk.

\section{Compliance with ethical standards}

Conflict of interest The authors declare that they have no conflicts of interest.

Open Access This article is distributed under the terms of the Creative Commons Attribution 4.0 International License (http://creative commons.org/licenses/by/4.0/), which permits unrestricted use, distribution, and reproduction in any medium, provided you give appropriate credit to the original author(s) and the source, provide a link to the Creative Commons license, and indicate if changes were made.

\section{References}

1. Di Lullo L, House A, Gorini A, Santoboni A, Russo D, Ronco C (2015) Chronic kidney disease and cardiovascular complications. Heart Fail Rev 20:259-272

2. Tucker PS, Scanlan AT, Dalbo VJ (2015) Chronic kidney disease influences multiple systems: describing the relationship between oxidative stress, inflammation, kidney damage, and concomitant disease. Oxid Med Cell Longev 2015:806358. https://doi. org/10.1155/2015/806358

3. Stenvinkel P (2006) Inflammation in end-stage renal disease: the hidden enemy. Nephrology 11:36-41

4. Miyamoto T, Carrero JJ, Stenvinkel P (2011) Inflammation as a risk factor and target for therapy in chronic kidney disease. Curr Opin Nephrol Hypertens 20:662-668
5. Fassett RG, Venuthurupalli SK, Gobe GC, Coombes JS, Cooper MA, Hoy WE (2011) Biomarkers in chronic kidney disease: a review. Kidney Int 80:806-821

6. Meuwese CL, Stenvinkel P, Dekker FW, Carrero JJ (2011) Monitoring of inflammation in patients on dialysis: forewarned is forearmed. Nat Rev Nephrol 7:166-176

7. Zhang W, He J, Zhang F, Huang C, Wu Y, Han Y, Zhang W, Zhao $Y$ (2013) Prognostic role of C-reactive protein and interleukin-6 in dialysis patients: a systematic review and meta-analysis. J Nephrol 26:243-253

8. Gupta J, Mitra N, Kanetsky PA, Devaney J, Wing MR, Reilly M, Shah VO, Balakrishnan VS, Guzman NJ, Girndt M, Periera BG, Feldman HI, Kusek JW, Joffe MM, Raj DS, CRIC Study Investigators (2012) Association between albuminuria, kidney function, and inflammatory biomarker profile in CKD in CRIC. Clin J Am Soc Nephrol 7:1938-1946

9. Krane V, Wanner C (2011) Statins, inflammation and kidney disease. Nat Rev Nephrol 7:385-397

10. Panichi V, Migliori M, De Pietro S, Taccola D, Bianchi AM, Giovannini L, Norpoth M, Metelli MR, Cristofani R, Bertelli AA, Sbragia G, Tetta C, Palla R, Colombo R (2002) C-reactive protein and interleukin-6 levels are related to renal function in predialytic chronic renal failure. Nephron 91:594-600

11. Panichi V, Maggiore U, Taccola D, Migliori M, Rizza GM, Consani C, Bertini A, Sposini S, Perez-Garcia R, Rindi P, Palla R, Tetta C (2004) Interleukin-6 is a stronger predictor of total and cardiovascular mortality than C-reactive protein in haemodialysis patients. Nephrol Dial Transplant 19:1154-1160

12. Scirica BM, Morrow DA (2006) Is C-reactive protein an innocent bystander or proatherogenic culprit? The verdict is still out. Circulation 113:2128-2151

13. Pasceri V, Willerson JT, Yeh ET (2000) Direct proinflammatory effect of C-reactive protein on human endothelial cells. Circulation 102:2165-2168

14. Pepys MB, Hirschfield GM (2003) C-reactive protein: a critical update. J Clin Invest 111:1805-1812

15. Verma S, Li SH, Badiwala MV, Weisel RD, Fedak PW, Li RK, Dhillon B, Mickle DA (2002) Endothelin antagonism and interleukin-6 inhibition attenuate the proatherogenic effects of C-reactive protein. Circulation 105:1890-1896

16. Verma S, Wang CH, Li SH, Dumont AS, Fedak PW, Badiwala MV, Dhillon B, Weisel RD, Li RK, Mickle DA, Stewart DJ (2002) A self-fulfilling prophecy: C-reactive protein attenuates nitric oxide production and inhibits angiogenesis. Circulation 106:913-919

17. Wang CH, Li SH, Weisel RD, Fedak PW, Dumont AS, Szmitko P, Li RK, Mickle DA, Verma S (2003) C-reactive protein upregulates angiotensin type 1 receptors in vascular smooth muscle. Circulation 107:1783-1790

18. Devaraj S, Xu DY, Jialal I (2003) C-reactive protein increases plasminogen activator inhibitor-1 expression and activity in human aortic endothelial cells: implications for the metabolic syndrome and atherothrombosis. Circulation 107:398-404

19. Ridker PM (2003) Clinical application of C-reactive protein for cardiovascular disease detection and prevention. Circulation 107:363-369

20. Ganter U, Arcone R, Toniatti C, Morrone G, Ciliberto G (1989) Dual control of C-reactive protein gene expression by interleukin-1 and interleukin-6. EMBO J 8:3773-3779

21. Alexander RW (1994) Inflammation and coronary artery disease. New Engl J Med 331:468-469

22. Danesh J, Collins R, Peto R (1997) Chronic infections and coronary heart disease: is there a link? Lancet 350:430-436

23. Mohamed-Ali V, Goodrick S, Rawesh A, Katz DR, Miles JM, Yudkin JS, Klein S, Coppack SWJ (1997) Subcutaneous adipose 
tissue releases interleukin-6, but not tumor necrosis factor-alpha, in vivo. Clin Endocrinol Metab 82:4196-4200

24. Cancello R, Tounian A, Poitou Ch, Clement K (2004) Adiposity signals, genetic and body weight regulation in humans. Diabetes Metab 30:215-227

25. Iannone F, Lapadula G (2010) Obesity and inflammation-targets for OA therapy. Curr Drug Targets 11:586-598

26. Norris CA, He M, Kang LI, Ding MQ, Radder JE, Haynes MM, Yang Y, Paranjpe S, Bowen WC, Orr A, Michalopoulos GK, Stolz DB, Mars WM (2014) Synthesis of IL-6 by hepatocytes is a normal response to common hepatic stimuli. PLoS ONE 9:e96053

27. Lau DC, Dhillon B, Yan H, Szmitko PE, Verma S (2005) Adipokines: molecular links between obesity and atheroslcerosis. Am J Physiol Heart Circ Physiol 288:H2031-H2041

28. Ouchi N, Kihara S, Funahashi T, Nakamura T, Nishida M, Kumada M, Okamoto Y, Ohashi K, Nagaretani H, Kishida K, Nishizawa H, Maeda N, Kobayashi H, Hiraoka H, Matsuzawa Y (2003) Reciprocal association of C-reactive protein with adiponectin in blood stream and adipose tissue. Circulation 107:671-674

29. Armendariz AD, Krauss RM (2009) Hepatic nuclear factor 1-alpha: inflammation, genetics, and atherosclerosis. Curr Opin Lipidol 20:106-111

30. Sucajtys-Szulc E, Szolkiewicz M, Swierczynski J, Rutkowski B (2016) Up-regulation of Hnfl $\alpha$ gene expression in the liver of rats with experimentally induced chronic renal failure - a possible link between circulating PCSK9 and triacylglycerol concentrations. Atherosclerosis 248:17-26

31. Toniatti C, Demartis A, Monaci P, Nicosia A, Ciliberto G (1990) Synergistic trans-activation of the human C-reactive protein promoter by transcription factor HNF-1 binding at two distinct sites. EMBO J 9:4467-4475

32. Reiner AP, Barber MJ, Guan Y, Ridker PM, Lange LA, Chasman DI et al (2008) Polymorphisms of the HNF1A gene encoding hepatocyte nuclear factor- 1 alpha are associated with C-reactive protein. Am J Hum Genet 82:1193-1201

33. Elliott P, Chambers JC, Zhang W, Clarke R, Hopewell JC, Peden JF et al (2009) Genetic Loci associated with C-reactive protein levels and risk of coronary heart disease. JAMA 302:37-48. https://doi.org/10.1001/jama.2009.954

34. Ley SH, Hegele RA, Connelly PW, Harris SB, Mamakeesick M, Cao H, Gittelsohn J et al (2010) Assessing the association of the HNF1A G319S variant with C-reactive protein in Aboriginal Canadians: a population-based epidemiological study. Cardiovasc Diabetol 9:39. https://doi.org/10.1186/1475-2840-9-39

35. Wu Y, McDade TW, Kuzawa CW, Borja J, Li Y, Adair LS, Mohlke KL, Lange LA (2012) Genome-wide association with C-reactive protein levels in CLHNS: evidence for the CRP and HNF1A loci and their interaction with exposure to a pathogenic environment. Inflammation 35:574-583

36. Liu R, Liu H, Gu H, Teng X, Nie Y, Zhou Z, Zhao Y, Hu S, Zheng $Z$ (2014) A polymorphism in hepatocyte nuclear factor 1 alpha, rs7310409, is associated with left main coronary artery disease. Biochem Res Int 2014:924105. https://doi. org/10.1155/2014/924105

37. Okada Y, Takahashi A, Ohmiya H, Kumasaka N, Kamatani Y, Hosono $\mathrm{N}$ et al (2011) Genome-wide association study for C-reactive protein levels identified pleiotropic associations in the IL6 locus. Hum Mol Genet 20:1224-1231

38. Vinayagamoorthy $\mathrm{N}, \mathrm{Hu} \mathrm{HJ}$, Yim SH, Jung SH, Jo J, Jee SH, Chung YJ (2014) New variants including ARG1 polymorphisms associated with C-reactive protein levels identified by genomewide association and pathway analysis. PLoS ONE 9:e95866. https://doi.org/10.1371/journal.pone.0095866

39. Shi H, Leng S, Liang H, Zheng Y, Chen L (2016) Association study of C-reactive protein associated gene HNF1A with ischemic stroke in Chinese population. BMC Med Genet 17:51. https://doi. org/10.1186/s12881-016-0313-3

40. Ryffel GU (2001) Mutations in the human genes encoding the transcription factors of the hepatocyte nuclear factor (HNF) 1 and HNF4 families: functional and pathological consequences. J Mol Endocrinol 27:11-29

41. Swierczynski J, Korczynska J, Szolkiewicz M, Karbowska J, Kochan Z, Nieweglowski T, Kusiak E, Rutkowski B (2001) Low leptin mRNA level in adipose tissue and normoleptinemia in experimental chronic renal failure. Exp Nephrol 9:54-59

42. Turyn J, Stojek M, Swierczynski J (2010) Up-regulation of stearol-CoA desaturase 1 and elongase 6 genes expression in rat lipogenic tissues by chronic food restriction and chronic food restriction/refeeding. Mol Cell Biochem 345:181-188

43. Zelewski M, Swierczynski J (1983) The effect of clofibrate feeding on the NADP-linked dehydrogenases activity in rat tissue. Biochim Biophys Acta 758:152-157

44. Chomczynski P, Sacchi N (1987) Single-step method of RNA isolation by acid guanidinium thiocyanate-phenol-chloroform extraction. Anal Biochem 62:156-159

45. Winer J, Jung CK, Shackel I, Williams PM (1999) Development and validation of real-time quantitative reverse transcriptase-polymerase chain reaction for monitoring gene expression in cardiac myocytes in vitro. Anal Biochem 270:41-49

46. Lau WL, Vaziri ND (2017) Urea, a true uremic toxin: the empire strikes back. Clin Sci 131:3-12

47. Munoz Mendoza J, Isakova T, Cai X, Bayes LY, Faul C, Scialla JJ, Lash JP, Chen J, He J, Navaneethan S, Negrea L, Rosas SE, Kretzler M, Nessel L, Xie D, Anderson AH, Raj DS, Wolf M, CRIC Study Investigators (2017) Inflammation and elevated levels of fibroblast growth factor 23 are independent risk factors for death in chronic kidney disease. Kidney Int 91:711-719

48. Feingold KR, Moser AH, Shigenaga JK, Patzek SM, Grunfeld C (2008) Inflammation stimulates the expression of PCSK9. Biochem Biophys Res Commun 374:341-344

49. Lemieux I, Pascot A, Prud'homme D, Almeras N, Bogaty P, Nadeau A, Bergeron J, Despres JP (2001) Elevated C-reactive protein: another component of the atherothrombotic profile of abdominal obesity. Arterioscler Thromb Vasc Biol 21:961-967

50. Nishikawa T, Hagihara K, Serada S, Isobe T, Matsumura A, Song J, Tanaka T, Kawase I, Naka T, Yoshizaki K (2008) Transcriptional complex formation of c-Fos, STAT3, and hepatocyte NF-1 alpha is essential for cytokine-driven C-reactive protein gene expression. J Immunol 180:3492-3501

51. Owen KR, Thanabalasingham G, James TJ, Karpe F, Farmer AJ, McCarthy MI, Gloyn AL (2010) Assessment of high-sensitivity C-reactive protein levels as diagnostic discriminator of maturityonset diabetes of the young due to HNF1A mutations. Diabetes Care 33:1919-1924

52. McDonald TJ, Shields BM, Lawry J, Owen KR, Gloyn AL, Ellard S, Hattersley AT (2011) High-sensitivity CRP discriminates HNF1A-MODY from other subtypes of diabetes. Diabetes Care 34:1860-1862

53. Reiner AP, Barber MJ, Guan Y, Ridker PM, Lange LA, Chasman DI, Walston JD, Cooper GM, Jenny NS, Rieder MJ, Durda JP, Smith JD, Novembre J, Tracy RP, Rotter JI, Stephens M, Nickerson DA, Krauss RM (2008) Polymorphisms of the HNF1A gene encoding hepatocyte nuclear factor-1 alpha are associated with C-reactive protein. Am J Hum Genet 82:1193-1201

54. Ridker PM, Pare G, Parker A, Zee RY, Danik JS, Buring JE, Kwiatkowski D, Cook NR, Miletich JP, Chasman DI (2008) Loci related to metabolic-syndrome pathways including LEPR, HNF1A, IL6R, and GCKR associate with plasma C-reactive protein: the Women's Genome Health Study. Am J Hum Genet 82:1185-1192 
55. Cheret C, Doyen A, Yaniv M, Pontoglio M (2002) Hepatocyte nuclear factor 1 alpha controls renal expression of the Npt1-Npt4 anionic transporter locus. J Mol Biol 322:929-941

56. Ridker PM (2009) C-reactive protein: eighty years from discovery to emergence as a major risk marker for cardiovascular disease. Clin Chem 55:209-215
57. Wang B, Cai SR, Gao C, Sladek FM, Ponder KP (2001) Lipopolysaccharide results in a marked decrease in hepatocyte nuclear factor 4 alpha in rat liver. Hepatology 34:979-989 